\title{
AppPECS: Mobile Application for Children with Autism Spectrum Disorder
}

\section{AppPECS: Una aplicación móvil para niños con trastorno del espectro autista}

\author{
ENRÍQUEZ-RAMÍREZ, Carlos†*, CRUZ-RESÉNDIZ, Juan Carlos, OLVERA-CUEYAR, Miriam and \\ SÁNCHEZ-HERRERA, Roberto Arturo
}

Universidad Politécnica de Tulancingo, División de Ingenierías.

ID $1^{\text {st }}$ Author: Carlos, Enríquez-Ramírez / ORC ID: 0000-0003-4963-9828, CVU CONACYT ID: 226383

ID $1^{\text {st }}$ Coauthor: Juan Carlos, Cruz-Reséndiz / ORC ID: 0000-0001-9319-4796, CVU CONACYT ID: 243068

ID $2^{\text {nd }}$ Coauthor: Miriam, Olvera-Cueyar / ORC ID: 0000-0002-4276-504, CVU CONACYT ID: 206820

ID $3^{\text {rd }}$ Coauthor: Roberto Arturo, Sánchez-Herrera / ORC ID: 0000-0003-4415-7934, CVU CONACY ID: 347249

\begin{abstract}
The study of treatments for children with autism and interventions through educational games is growing because researchers have seen an acceptance by users with autism spectrum disorder in this type of applications. Allowing this type of users to acquire and develop new skills such as digital, the development of writing through the use of the keyboard, as a means of communication and a mechanism of reinforcement in sociable aspects. Taking into account the benefits of using games through mobile applications in the treatment of targeted therapies in children with autism spectrum disorder, a mobile application has been developed to obtain an experience that interactively stimulates children for the purpose of Reinforce areas of learning development, such as repetition of activities (socialization), concentration, reinforcement of short-term memory, order and development of kinesthetic skills through the use of digitization. This project was applied in the Unidad de Servicios de Apoyo a la Escuela Regular No. 21 (USAER) instance of Special Education, dependent on the Secretaría de Educación Pública de Hidalgo.
\end{abstract}

Digital skills, Autism, Mobiles application

\begin{abstract}
Resumen
El estudio de los tratamientos para niños con autismo e intervenciones a través de juegos educativos está en crecimiento debido a que los investigadores han visto una aceptación por parte de los usuarios con trastorno de espectro autista. Lo anterior permite a este tipo de usuarios adquirir y desarrollar nuevas habilidades como pueden ser las digitales, el desarrollo de la escritura mediante el uso del teclado como un medio de comunicación y un mecanismo de reforzamiento en aspectos sociables. Tomando en cuenta los beneficios del uso de juegos mediante las aplicaciones móviles en el tratamiento de terapias dirigidas en los niños con trastorno de espectro autista, se ha desarrollado una aplicación móvil para obtener una experiencia que estimule de manera interactiva a los niños, con la finalidad de reforzar áreas de desarrollo del aprendizaje como es la repetición de actividades (sociabilización), concentración, el reforzamiento de la memoria a corto plazo, el orden y el desarrollo de habilidades kinestésicas mediante el uso de la digitalización. Este proyecto se aplicó en la instancia de Educación Especial de la Unidad de Servicios de Apoyo a la Escuela Regular No. 21 (USAER), dependiente de la Secretaría de Educación Pública de Hidalgo.
\end{abstract}

Habilidades digitales, Autismo, Aplicaciones móviles

Citation: ENRÍQUEZ-RAMÍREZ, Carlos, CRUZ-RESÉNDIZ, Juan Carlos, OLVERA-CUEYAR, Miriam and SÁNCHEZHERRERA, Roberto Arturo. AppPECS: Mobile Application for Children with Autism Spectrum Disorder. Journal-Spain. 2019. 6-10: $27-38$

\footnotetext{
* Correspondence to Author (carlos.enriquez@upt.edu.mx)

$\dagger$ Researcher contributing as first author.
} 


\section{Introduction}

Autism spectrum disorder (ASD) is a general term that describes a series of individuals who have atypical behaviors in two diagnostic settings: social communication and restricted or repetitive behaviors (A.P.A., 2013). It is also associated with language delays and intellectual disability in a large proportion of cases (Fombonne, 2005).

Atypics in social interaction can manifest as difficulty in understanding nonverbal behavior (Mundy \& Neal, 2001), and understanding the thoughts, beliefs and intentions of others (Baron-Cohen, Leslie, \& Frith, 1985), and peer relationships (Calder, Hill, $\&$ Pellicano, 2012). The domain of restricted and repetitive behaviors can manifest as a need for uniformity and routine, or as an inability to generalize information (Leekman, Prior, \& Uljarevic, 2011).

Advances in digital technology can contribute to broadening the focus to educators, health professionals and others in the integral development of children with ASD (Pontes, et al., 2019). Several investigations have suggested that computer assistance can be used to teach some skills to children with ASD, such as the one proposed by Pennington (2010), which suggests that computer assistance can be effective in teaching academic skills, specifically as literature to students with ASD (King, Thomeczek, Voreis, \& Scott, 2014).

Within the technology, there is mobile technology such as smartphones or tablets, the latter, due to its technical characteristics, facilitate some tasks for users besides communication, some of these are: as assistants to individuals with ASD in the academic area, in the reinforcement of social areas, in the modeled video, as reinforcement of language therapies, in the development of fine motor skills, as visual support, in life development skills, in the organizational capacity and in increasing independence.

In summary Cantabran (2019) indicates that technology, in this case the mobile, is an effective communication strategy in the face of an emergency situation between external elements and the autism patient.
Using the technological capabilities that tablets provide in individuals with ASD, the use of the AppPECS application, based on the Image Exchange Communication System (PECS), which is a digital form of Alternative communication developed to teach children who have limited speech, in order to strengthen some skills (Bondy \& Frost, 1994), taking advantage of the fact that mobile devices are a bridge of communication in most autistic children, allowing their language progresses little by little as it affirms (Hill \& Frith, 2003).

Mobile technology has penetrated education and through this device students with ASD develop or strengthen certain capabilities such as: communication, digitization skills, language, writing through a keyboard, among others (Law \& Neihart, 2019 ). It is essential for an autistic child to maintain interest in what he learns because they are easily distracted, but with the help of mobile device technology such as iPads ${ }^{\circledR}$ they can focus their attention, motivating them to develop activities that strengthen their skills. Due to the display characteristics of this device, it becomes one of the strengths (Schmidt \& Heybyrne, 2004) and the use of touch technology, that is, touching and dragging objects in the screen environment, allowing the development of digital skills because some people with autism find that writing on paper is an aversivity, so they prefer to use a touch screen or keyboard for written expression (Kluth \& Danaher, 2010).

Due to the variety of multimedia elements, children with ASD are conducive to the identification of emotions as seen in (Nieves, Hamburger, Vargas, \& Escobar, 2019), through graphic and interactive support arousing interest, such as that is proposed in this work.

Among the contributions that an $\mathrm{iPad} \AA$ presents, there is the increase in attendance in children with ASD, so it has become a popular device for education in students with these neurological characteristics; This is due to the particularity of having a touch screen, personalization in educational materials and a wide variety of educational applications (Neely, 2013). The versatility of the device is one of the aspects that gives the possibility of integration with children with ASD at work. This can be observed in the research proposed by (Murdock, Ganz, \& Crittendon, 2013) where its use is directed towards strengthening the ability to play.

ENRÍQUEZ-RAMÍREZ, Carlos, CRUZ-RESÉNDIZ, Juan Carlos, OLVERA-CUEYAR, Miriam and SÁNCHEZ-HERRERA, Roberto Arturo. AppPECS: Mobile Application for Children with Autism Spectrum Disorder. Journal-Spain. 2019 
In (Neely et al., 2013) it is used to increase academic participation; in (Lorah et al., 2013), as a voice generator. Kagora et al. (2013) provides a review of the literature on the use of iPads ${ }^{\circledR}$ and iPods $\AA$ in individuals with developmental disabilities. The review identifies 15 articles that show that these devices have been used for academic tasks, communication teaching, leisure skills development, among others. Taking into account these advantages of technology, the portable nature and attractiveness of iPads ${ }^{\circledR}$ and its easy-to-use touch screens, they provide instant gratification for children with ASD.

Due to the benefit of mobile applications developed on an iPad ${ }^{\circledR}$ platform or on any other touch device for children with ASD in their special learning process such as those mentioned in (Weng \& Bouck, 2019); (Parsons, Wilson, \& Vaz, 2019). This work aims to demonstrate the use of the AppPECS application, which is its own mobile application, developed at the Polytechnic University of Tulancingo by students of the Computer Systems career, aimed at strengthening digital skills and using semantic fields for language strengthening through the use of constructs to children with ASD in a limited semantics. The application software engineering was done by university-level students applying an operation construction methodology that is based on the plan-do-verify-act cycle.

Through this period, the specifications of the psychologists and pedagogues were obtained to carry out the design and construction of the solution taking as a central element the use of pictograms, taking advantage of the visual capacity that children with ASD have and thus adapting visual elements that facilitate the activities that were dictated by specialists. Research questions focus on analyzing whether a mobile phone application, designed specifically for children with ASD, (P1) can encourage learning and help improve some of their fundamental skills, such as language and social skills. In addition, we have tried to explore the ability of the mobile application to improve the learning process, all in an interactive and playful way so that it attracts the attention of children. This type of application should strengthen the child's therapy process to maintain attention and iteration with the health professional (P2) by identifying the quality of work time that is had with the child during the use of the application.
Finally, from a point of software engineering the design characteristics are evaluated, that is, if it is applicable in an easy and intuitive way for use by the child with ASD. For the appraisal of the application, an experimental design was applied in five children, working together with the Unit of Support Services to the Regular School (USAER 21) of Hidalgo that allowed access to the program of children with Special Educational Needs (NEE) to have the opportunity for children with ASD characteristics to use the AppPECS as an element of gamification as proposed in Godoy (2019), that is, the way to use game-based mechanics, aesthetics and thinking of the game, this, in order to motivate people, promote learning and solve problems.

\section{Methodology}

For the development of AppPECS, the requirements were raised based on the review of research papers related to the usability of mobile applications in children with ASD, in addition to interviews with USAER 21 specialists and the observation that during 8 months The work carried out by therapists (psychologists and pedagogues) was carried out in the field where the treatment of children with ASD was carried out. Prototypes of the work were carried out to show the previous designs and the explanation of how the functionality would be finally the coding was done in a programming language for the construction of the application, we worked in the integration environment xcode ${ }^{\circledR}$.

The application was used exploratoryly in five children with ASD examining the effects on the intervention through the use of the AppPECS by specialists in the children selected directly to examine the effectiveness of the application, based on the results of the previous evaluations (Yee, 2004) such as those shown in the results section and thus iteratively improve the final version. In the following sections the implementation methodology is detailed.

\section{Participants}

For the evaluation with the end user, five students were selected according to the specification of the number of stakeholders required to evaluate a mobile application (it is proposed that it be made from 5 to 10 users) Kaikkonen, Kekäläinen, Cankar, Kallio, \& Kankainen, 2005. 
The application was used by children with ASD and the data that originated was recorded in a data container housed in the device. For example, the subject they worked on, the duration and number of movements were recorded according to the activity carried out. The children involved in the test have been in a therapy process between 12 and 18 months. The grade of ASD has been diagnosed by the USAER 21 specialist based on a previous diagnostic process, most of them show problems with communication, language and learning skills. The criteria used for the evaluation of the application, was based on the age of the users and the level of learning disability. In the following sections a description is made of the phases that were carried out for the construction and release of the application.

\section{Process}

Through multidisciplinary work sessions formed by psychologists and education specialists, both functional and non-functional requirements of users were obtained. Presenting the types of skills that you want to strengthen in the end users, such as: the identification of words, the reinforcement of immediate memory, the identification of images and colors, ordering of figures, use of sequences for social interaction, traceability of figures by using image coloring and reading. For the presentation of the requirements it is important to mention that:

Primary users are children with ASD and their caregivers are secondary users.

The use of the scenarios depends on the cognitive abilities of the users.

Demand 16 scenarios, with different activities that help to reinforce a specific skill. In addition to obtaining the metric of successes and working times in each of the options. The therapist can see the section where the work information of the end user is stored individually and together. And also, the activities can be selected at random, that is, there is no circuit of activities as such.

For the definition of both functional and non-functional requirements, they were segmented into priorities (high and low) in order to give a hierarchy in the application development process, in the following sections both segments are detailed:
High priority functional requirements. They include activities that help end users to develop or strengthen the fields of sociability, written communication, immediate memory, sequence of orders, drawing and coloring of figures, in addition to developing the ability to concentrate; in order to develop competencies in daily life and thus have a reinforcement in achieving it. In addition to motivating the child with ASD to carry out the activities, as well as establish a feedback on them.

The low priority functional requirements allow to customize the activities of the end user and have a historical record of the activities, time, successes and dates of work. This allows to have elements for the therapist to work in the new sessions reinforcing the activities not yet reified in the child with ASD.

For high priority, over non-functional requirements, the application must be compatible with $\mathrm{iPad} \AA$ devices and iOS operating system. In this way, making the usability of the activities attractive to the end users as mentioned in (Schmidt \& Heybyrne, 2004).

One of the characteristics of importance in the construction of applications for this type of users is that it should not contain distracting elements such as sounds or buttons; In addition, it must be appropriate for the age of the participants. The reason is because the user must be kept focused on the purpose of the ability to reinforce or generate.

According to ISO 9126, the usability feature is defined by "The ability of the software product to be understood, learned, managed and attractive to the user, when used under specified conditions" this is subdivided into four basic features: 1 ) Understanding: "the ability of the product to allow the user to understand if the software is suitable and how it can be used for specific tasks and conditions of use". 2) Learning: "the ability of the software product to allow the user to learn". 3) Operability: "the ability of the software product to allow the user to operate and control it". 4) Attractiveness: "the ability of the software product to be attractive to the user". 
Taking into account the four previous characteristics, a series of activities were designed based on the ability of children with ASD to acquire new skills independently with computer technology as documented (Pennington, 2006) and (Roschelle, Pea, Hoadley , Gordin, \& Means, 2001), in addition to allowing to generate stimuli, correctly reinforce responses and demonstrate errors under the strict control of the caregiver.

Davis et al., Recommend that the specific factors that should be taken into account when designing learning environments for these types of users in order to improve their strengths and reduce the need for skills that are difficult for them to develop or carry out, they are tasks that are consistent, predictable and gradually introduce novel elements (Weiss, et al., 2011). Taking as reference to these authors, the lifting of the requirements and making use of the PECS concept, the application has been developed so that users can communicate their wishes or needs as indicated in (Bondy \& Frost, 1994).

Once the application is finished, it was implemented on the iPad so that users with autism will carry out their recreational activities and strengthen skills such as: the development of their digital capabilities at first sight and other skills described in the following sections.

In the process of design, development and evaluation it was necessary to integrate an interdisciplinary team, involving close collaboration between the humanities and technology areas, working together as design partners. One of the challenges was to convey the therapeutic objectives of the application and formulate them in specific recommendations for its creation. The design team assisted in determining the details of the project, and the programmers had to write code to produce the desired results. A specific example of this process was the need to ensure that each application scene seemed different, avoiding boredom or mechanization of responses by repeating activities.

\section{Description of the application and activities}

AppPECS is an interactive software, aimed at children and young people with ASD, which reinforces the verbal process, the use of immediate memory, the socialization of certain behaviors and the use of their digital skills.
The application consists of 16 activities that are presented in the following sections. Due to the delay or partial lack of oral language presented by children with autism, there is a need to compensate for this failure through alternative modes of communication such as pictograms, which, as will be seen in each of the actions, are used to recreational and learning purposes.

In Fig. 1 there is a screen for the validation of the user with the option of registering for the first time or giving access to the student in order to have an individualized registration of the child with ASD and follow up on their activities.

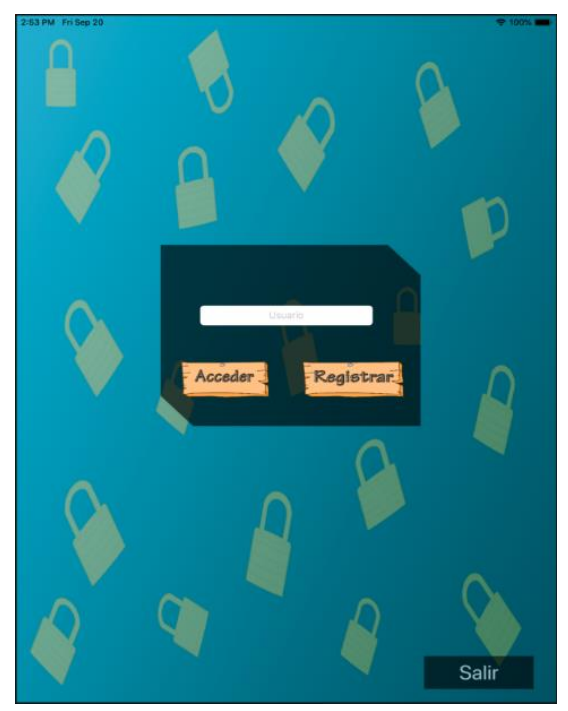

Figure 1 Registration screen to access the application as a user

Source: Self Made

Fig. 2 shows a view that represents the menu of options that the therapist can suggest as a guide in the work session.

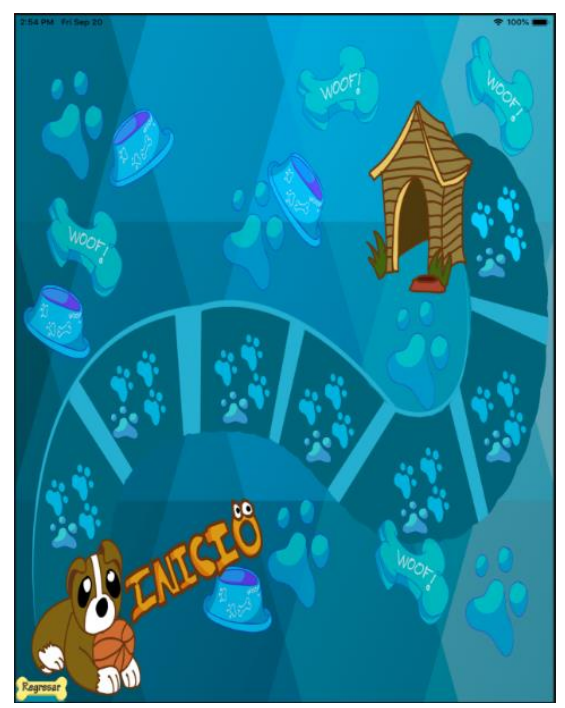

Figure 2 Section for selecting options for the activity to be carried out

Source: Self Made

ENRÍQUEZ-RAMÍREZ, Carlos, CRUZ-RESÉNDIZ, Juan Carlos, OLVERA-CUEYAR, Miriam and SÁNCHEZ-HERRERA, Roberto Arturo. AppPECS: Mobile Application for Children with Autism Spectrum Disorder. Journal-Spain. 2019 
Because people with ASD have difficulty interpreting social cues or their behavior is not as expected in situations of daily life and because they are unaware of the consequences of their actions or the difficulty of understanding how their behavior affects others, It makes use of the concept of social narratives, which has been used to mitigate these deficits. These narratives tell step by step (with simple texts and figures) how to act in real life situations (Gray, 2000).

Through the activities shown in Fig. 3-4, the concept of social narratives is implemented, that is, interventions that describe social situations in some detail, highlighting the relevant signals, offering in this case two instances that are the sequences of Go to school and bathe. They adapted to help students adjust their routine changes and accommodate their behaviors based on the social and physical signals of a situation.

The games to complete the word were designed with the intention of developing the ability to form words, comprehension, and identification of how the symbol displayed on the device is written, in addition to promoting the ability to use the keyboard.

The vowels are an integral part of the learning process of written reading in all people. For children who have ASD, having limited verbal abilities does not achieve the interaction of vowels with consonants, therefore the articulation of sentences is difficult. The use of a word and correspondence with the object and / or symbol allows the development of an oral language in the child as well as a linguistic skill.

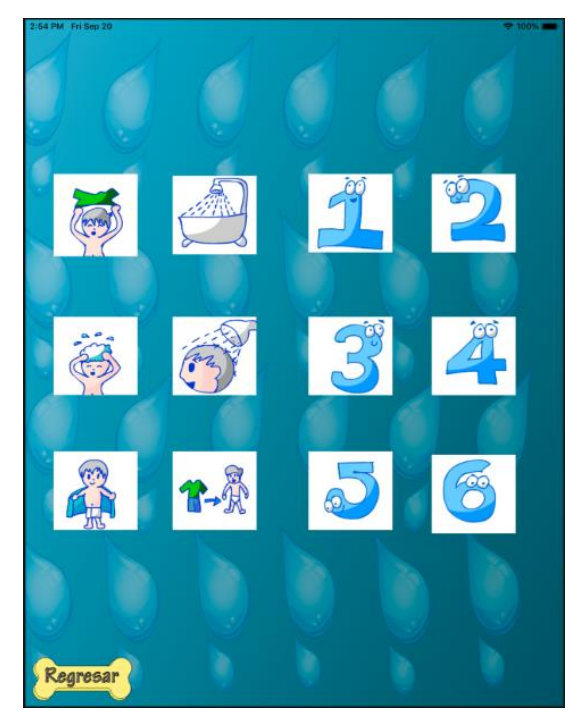

Figure 3 Exercise sequences of activities before going to school

Source: Self Made

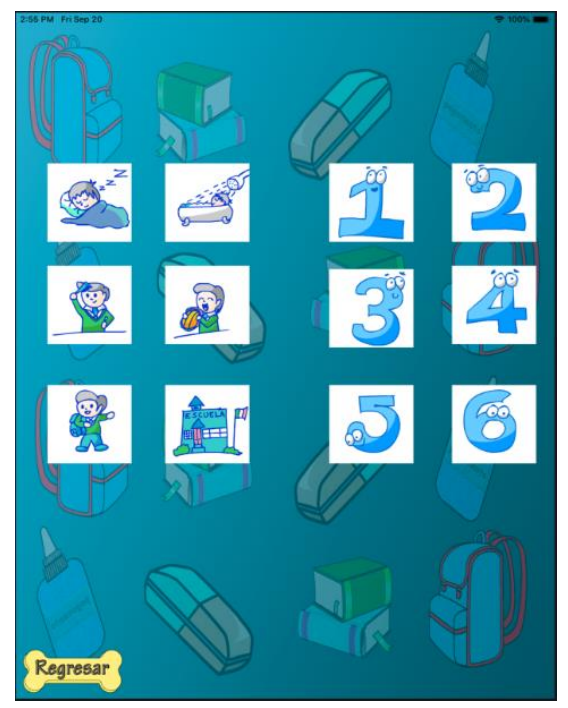

Figure 4 Exercise that indicates the sequence of activities when bathing

Source: Own Elaboration

Because some autistic children make efforts to accommodate their sensory and visual motor skills on paper, some students with autism fail to make these accommodations successfully due to the speed of writing and readability. For some students with ASD, touch-screen technologies, scanning and voice-to-text technologies can offer handwriting alternatives that allow you to generate written texts independently, but in a digital format (Coffin, Myles, Rogers, \& Szakacs, 2016).

Often you can use your finger to create letters / words / phrases that are displayed on the screen without holding a writing element, which allows the student to develop the kinesthetic sensation of letter formation, this can also be achieved with The application shown in Fig. 5 which is a drawing application, that is, this activity helps students with ASD to understand the traces that are made on paper and that make sense.

In addition, it allows to develop a stimulus in the fingers while motivating the practice of their fine motor skills in other areas such as handwriting and the use of a keyboard. 


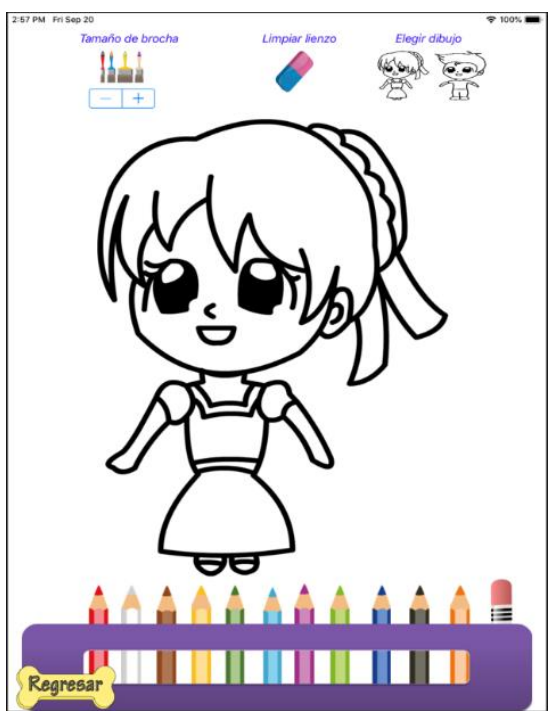

Figure 5 Colored area

Source: Self Made

Another session is the assembly of Tangram, which contains 9 forms as shown in Fig. 6 to assemble (House, Swan, Elephant, Chicken, Rabbit, Number 1, Letter A, Dog, Triangle). In which, by means of a guide drawing, it tells the student with ASD which piece should be placed and where. The application captures the number of movements the child makes and the time it takes to achieve the figure.

The pieces as seen in Fig. 7 have characteristics of color and various geometric shapes, which can reinforce concepts such as: circle, square, triangle, pentagon and rhombus.

The Tangram has the ability to improve various skills, such as imagination, spatial visualization, logic, concentration, spatial geometric thinking and knowledge of mathematics (Greczek, Kaszubski, Atrash, \& Mataric, 2014). During the game the child drags the figure with his finger to the right place, when the piece is in its place, the puzzle is covered, at that moment a screen describing the achievement of the activity is displayed, together with the number of movements registered and the times of having obtained the result.

There are several levels of complexity depending on the form, so that the child with ASD does not lose curiosity and avoid stress, so the level of armed tangram is indicated by the therapist.

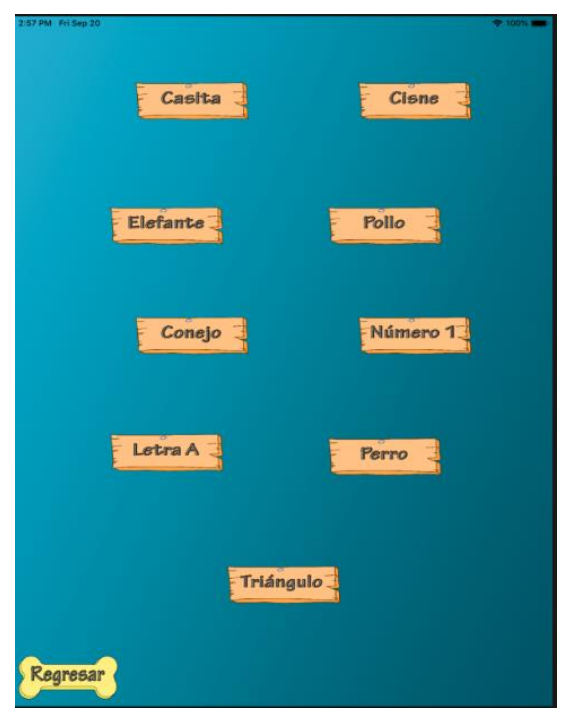

Figure 6 Tangrams set Source: Self Made

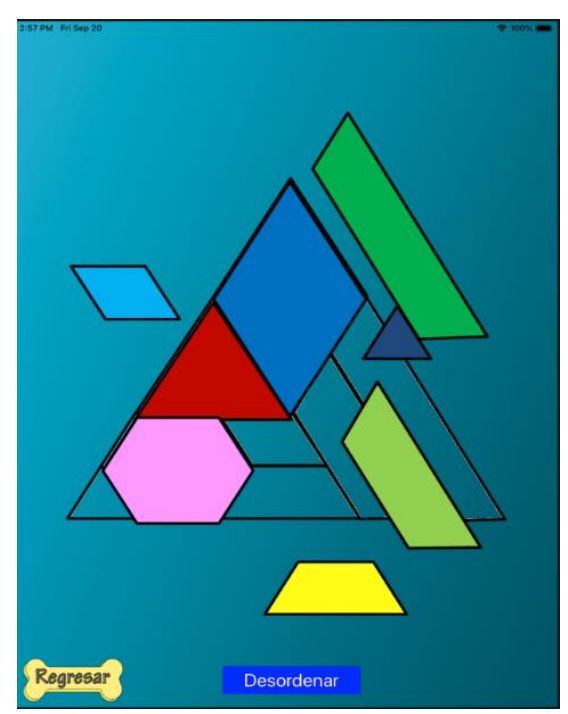

Figure 7 Messy Tangram example Source: Self Made

This activity is reinforced with the memo set as shown in Fig. 8, which presents different levels of complexity ranging from $4,16,32$ and 64 images. The purpose is to work with fine motor skills and your immediate visual and memory ability. 


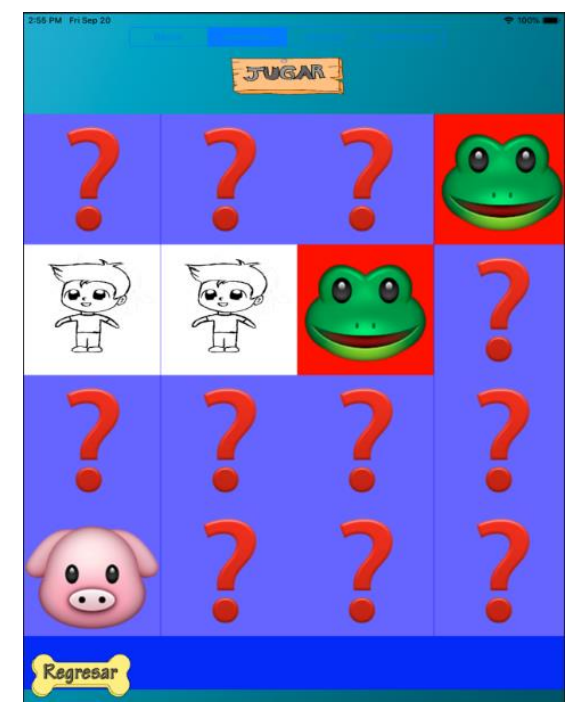

Figure 8 Memorization game Source: Self Made

In each of the activities the name of the child, the beginning and end of the activity, as well as the number of movements performed in the activities are recorded, such as: the arrangement of figures and sequences as shown in Fig. 9, according to the demand that in the study of (Cisnero, Juárez-Ramírez, \& Figueroa, 2016) indicates, where it is mentioned that the games of children with ASD do not provide an analysis of data or visualization tools that present progress and development of the child's skills.

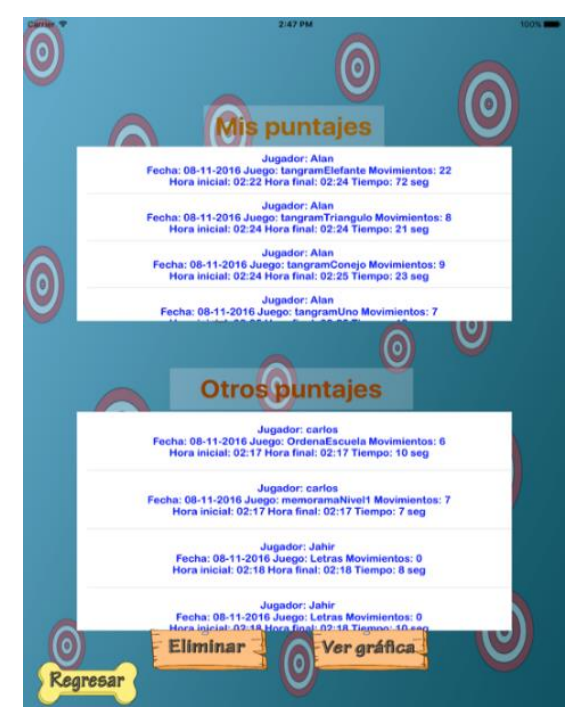

Figure 9 Individual and historical Scoring Session of other students

Source: Self Made

The non-functional requirements requested by the therapist are implemented in order to obtain information on the activities of children with ASD, which are shown in Fig. 910.
Based on the parameters, the evaluation of the usability of the application was carried out by observing the therapist when identifying the interest, in addition to understanding the correct procedure and actions of each of the activities that make up the application.

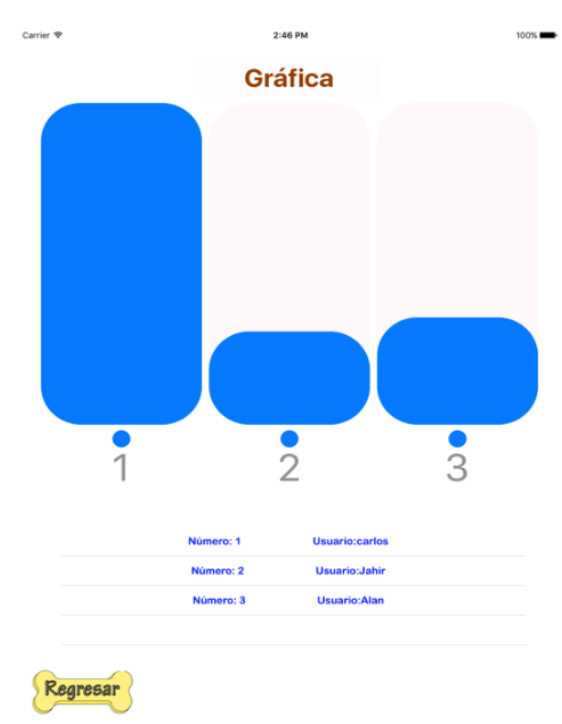

Figure 10 Advance chart per user Source: Self Made

Therapist's perceptions data is concentrated in Table I.

\begin{tabular}{|c|c|c|c|c|c|}
\hline 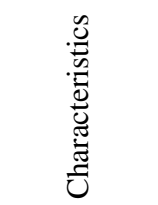 & 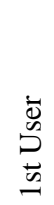 & 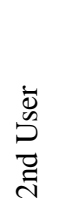 & 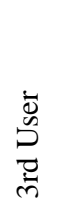 & 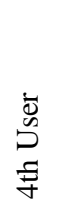 & $\begin{array}{l}\bar{u} \\
\stackrel{0}{0} \\
\tilde{D} \\
\dot{n}\end{array}$ \\
\hline Age (years) & 14 & 15.7 & 13.1 & 13.3 & 13.6 \\
\hline $\begin{array}{l}\overline{\bar{v}} \\
\bar{\Xi} \\
0\end{array}$ & $\frac{\frac{0}{\pi}}{\sum^{\pi}}$ & $\frac{\frac{0}{\pi}}{\Sigma}$ & $\frac{\stackrel{0}{\pi}}{\Sigma}$ & $\frac{\stackrel{0}{\pi}}{\Sigma}$ & $\frac{\stackrel{0}{\pi}}{\Sigma}$ \\
\hline 会 & $\frac{50}{.00}$ & 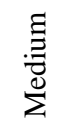 & $\frac{50}{600}$ & 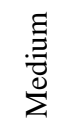 & 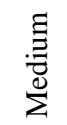 \\
\hline 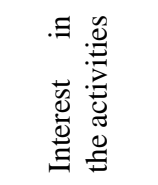 & 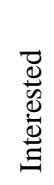 & 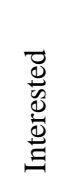 & 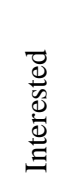 & 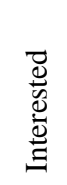 & 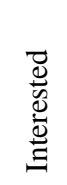 \\
\hline 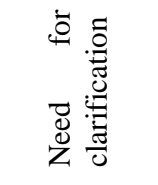 & No & Yes & Yes & 苛 & Yes \\
\hline 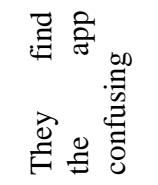 & No & No & No & No & No \\
\hline
\end{tabular}

Table 1 Students involved in the evaluation process Source: Self Made 
The selection of the control group was made up of five students with an average age of 13 years, all of them reported with characteristics of ASD and learning and socialization problems.

\section{Results}

To evaluate the use of the application, an observation process was carried out where all the students showed preference for the use of the applications instead of carrying out paper activities. The application was aimed at capturing the attention of children with ASD, students with a high level of autism showed higher levels of time to complete activities than children with mild symptoms. In response to question number one, if a mobile application can encourage learning and help improve some of its fundamental skills, such as language and social skills, we identify in preliminary data an increase in overall scores in a short time frame.

Analyzing the data it was observed that the students had an improvement in the identification of the images, word recognition, increase in digital skills and the use of the keyboard; In addition to showing an interest in the functionality of the application. Students managed to enjoy the application while they learned or reinforced cognitive structures. Some students managed to reify the semantic fields used in the application. Finally, with the application we encourage children the ability to interact using a mobile device in their therapy.

\section{Conclusions}

In this work, we present the development of an application to support children with ASD to help them develop digital skills and also develop or strengthen the fields of sociability, written communication, immediate memory, sequence of orders, tracing and coloring of figures, as well as concentration through the use of various activities that were implemented in it. Highlighting that the application is not the panacea in its use in the practices of strengthening the activities of the specialist with the child with ASD, but is seen as an extra tool. According to the specialist, the use of the AppPECS allows to stimulate the capacity of attention in the activities proposed to children.
In this work we focus on the development of the mobile application which can enhance learning by improving one of its basic skills. Although some preliminary results are shown in this work, it gives us interesting perspectives of the use of mobile applications in the field of therapy with ASD children with which the application can be enriched and its use in children who showed progress in performance in short periods of time.

\section{Acknowledgement}

We thank the children for their collaboration in the use of the mobile application and the specialists of the USAER 21, Hidalgo, Mexico.

\section{References}

25010:2011, I. (2017). ISO/IEC 25010:2011 Systems and software engineering -- Systems and software Quality Requirements and Evaluation (SQuaRE) - System and software quality models.

Ahmad, W. F., \& Azahari, I. N. (2015). Visual Approach of a Mobile Application for Autistic Children: Little Routine. In HCI International 2015-Poster's Extended Abstract, 436-442.

A.P.A. (2013). DSM-5, American Psychiatric Association.

Azahari, I., Ahmad, W. F., \& Hashim, A. S. (2015). Preliminary Study on Social Learning Using Mobile Technology Among Children with Autism. In Advances in Visual Informatics, 420431.

Baharuddin, R., Singh, D., \& Razali, R. (2013). Usability dimensions for mobile applications. A review Res. J. Appl. Sci. Eng. Technol., 5, 22252231.

Baron-Cohen, S., Leslie, A., \& Frith, U. (1985). Does the autistic child have a 'theory of mind?'.

Bondy, A. S., \& Frost, L. A. (1994). The picture exchange communication system. Focus on Autism and Other Developmental Disabilities, 9 (3), 1-19.

Calder, L., Hill, V., \& Pellicano, E. (2012). Sometimes i want to play by myself: Understanding what friendship means to children with autism in mainstream primary schools. Autism.

ENRÍQUEZ-RAMÍREZ, Carlos, CRUZ-RESÉNDIZ, Juan Carlos, OLVERA-CUEYAR, Miriam and SÁNCHEZ-HERRERA, Roberto Arturo. AppPECS: Mobile Application for Children with Autism Spectrum Disorder. Journal-Spain. 2019 
Cisnero, A. Q., Juárez-Ramírez, R., \& Figueroa, A. M. (2016). Towards a methodology for the learning of emotions for children with autism. In Learning Objects and Technology (LACLO) (pp. 1-6). Latin American Conference on IEEE.

Coffin, A. B., Myles, B. S., Rogers, J., \& Szakacs, W. (2016). Supporting the writing skills for individual with autism spectrum disorder through assistive technologies. In G. Lancioni, \& N. N. Singh, Assistive technologies for people with diverse abilities (pp. 59-73). LA, USA.

Coursaris, C. K., \& Kim, D. J. (2011). A metaanalytical review of empirical mobile usability studies. J. Usability Stud., 6.

Davis, M., Dautenhahn, K., Powel, D., \& Nehaniv, L. (2010). Guidelines for researchers and facilitators designing software and software trials for children with autism. Journal of Assistive Technologies, 4, 38-48.

Dawson, G., Jones, E., Merkle, K., Venema, K., Lowy, R., \& Faja, S. (2012). Early behavioral intervention is associated with normalized brain activity in young children with autism. Journal of the American Academy of Child \& Adolescent Psychiatry, 51 (11), 1150-1159.

Dawson, G., Rogers, S., Munson, J., Smith, M., Winter, J., \& Greenson, J. (2010). Randomized, controlled trial of an intervention for toddlers with autism: The Early Start Denver Model. Pediatrics, 125 (1), e17-e23.

Diggle, T., McConachie, H. R., \& Randle, V. R. (2009). Parent-mediated early intervention for young children with autism spectrum disorder. In John Wiley \& Sons (pp. 1-30). UK.

Elffers, J. (1976). Tangram: The Ancient Chinese Shapes Game. Penguin Books.

Fernández, A., Insfran, E., \& Abrahão, S. (2011). Usability evaluation methods for the web: A systematic mapping study. Inf. Softw. Technol., 53, 789-817.

Fombonne, E. (2005). The changing epidemiology of autism.

Godoy, M. (2019). Gamification from a theoretical reflection as a strategic resource in Education. Espacios, 40(15), 25.
Gray, C. A. (2000). Writing social stories with Carol Gray. Arlington, TX: Future Horizons.

Greczek, J., Kaszubski, E., Atrash, A., \& Mataric, M. J. (2014). Graded cueing feedback in robot-mediated imitation practice for children with autism spectrum disorders. Proceedings of the IEEE International Symposium on Robot and Human Interactive Communication., (pp. 561566).

Hill, D. A., \& Flores, M. M. (2014). Comparing the picture exchange communication system and the iPad for communication of students with autism spectrum disorder and developmental delay. TechTrends, 58 (3), 45-53.

Hill, E. L., \& Frith, U. (2003). Understanding autism: insights from mind and brain. In Philos. Trans. R. Soc. Lond. B Biol. Sci. (Vol. 358, pp. 281-289).

ISO/IEC. (n.d.). International Organization for Standardization ISO/IEC 9126-1 Quality model. Johnson, C. P., \& Myers, S. M. (2007). Identification and evaluation of children with autism spectrum disorders. Pediatrics, 120 (5), 1183-1215.

Jordan, K. A., \& Lofland, K. B. (2016). Collaborative Teaming: OT and SLP Cotreatment of Autism Spectrum Disorder. In $\mathrm{n}$ Technology and the Treatment of Children with Autism Spectrum Disorder (pp. 49-57). Springer International Publishing.

Jordan, R., Jones, G., \& Murray, D. (1988). Educational interventions for children with autism: A literature review of recent and current research.

Kaikkonen, A., Kekäläinen, A., Cankar, M., Kallio, T., \& Kankainen, A. (2005). Usability Testing of Mobile Applications: A Comparison between Laboratory and Field Testing. Journal of Usability Studies, 1 (1), 4-17.

Kamaruzaman, M. F., Rani, N. M., Nor, H. M., \& Azahari, M. H. (2016). Developing user interface design application for children with autism. Procedia-Social and Behavioral Sciences, 271, 887-894. 
King, A. M., Thomeczek, M., Voreis, G., \& Scott, V. (2014). iPad ${ }^{\mathrm{TM}}$ use in children and young adults with Autism Spectrum Disorder: An Observational study. Child Language Teaching and Therapy, 30 (2), 159-173.

Kluth, P., \& Danaher, S. (2010). From tutor scripts to talking sticks: 100 ways to differentiate instruction in K-12 inclusive classrooms. Maryland: Brooks Publishing.

Leekman, S. R., Prior, M. R., \& Uljarevic, M. (2011). Restricted and repetitive behaviors in autism spectrum disorders: A review of research in the last decade. Psychol. Bull., 137 (4), 562.

Lin, C. P., Shao, L. H., Wong, Y. J., \& Li, J. (2011). The impact of using synchronous collaborative virtual tangram in children's geometric. The Turkish Online J. Educ. Technol. (TOJET), 10 (2), 250-258.

Lofland, K. B. (2016). The Use of Technology in the Treatment of Autism. In J. L. Matson, \& B. Rouge, Technology and the Treatment of Children with Autism Spectrum Disorder (pp. 27-35). Utah, USA: Springer International Publishing.

López, J. M., Urretavizcaya, M., Losada, B., \& Fernández, I. (2016). Field vs. Laboratory Usability Evaluations: a Study on a Context Dependent Mobile Application Developed with an Agile Methodology. IEEE LATIN AMERICA TRANSACTIONS, 14 (1), 339-348. Lora, E. R., Parnell, A., \& Speight, R. D. (2014). Acquisition of sentence frame discrimination using the $\mathrm{iPad}^{\mathrm{TM}}$ as a speech generating device in young children with developmental disabilities. Research in Autism Spectrum Disorders, 8 (12), 1734-1740.

Lorah, E. R., Tincani, M., Dodge, J., Gilroy, S., Hickey, A., \& Hantula, D. (2013). Evaluating picture exchange and the $\mathrm{iPad}^{\mathrm{TM}}$ as a speech generating device to teach communication to young children with autism. Journal of Developmental and Physical Disabilities, 25 (6), 637-649.

Law, G., \& Neihart, M. (2019). Increasing intervention fidelity among special education teachers for autism intervention: A pilot study of utilizing a mobile-app-enable training program. Research in Autism Disorders.
Matera, M., Rizzo, F., \& Carughi, G. T. (2006). Web Usability: Principles and Evaluation Methods. Mosley, N., and Mendes, E. (Eds.), Web Engeneering, 143-180.

Mirenda, P. (2003). Toward functional augmentative and alternative communication for students with autism: Manual signs, graphic symbols, and voice output communication aids. Language, speech, and hearing services in schools, 34 (3), 203.

Moore, M., \& Calvert, S. (2000). Brief report: Vocabulary acquisition for children with autism: Teacher or computer instruction. Journal of autism and developmental disorders, 359-362.

Mundy, P., \& Neal, A. R. (2001). Neural plasticity, join attention and a transactional social-orienting model of autism.

Murdock, L. C., Ganz, J., \& Crittendon, J. (2013). Use of an iPad play story to increase play dialogue of preschoolers with autism spectrum disorders. Journal of autism and developmental disorders, 43 (9), 2174-2189.

Murray, J. (2014). Using Augmentative and Alternative Communication Interventions to Increase Functional Communication for Children with Autism Spectrum Disorder. BU Journal of Graduate Studies in Education, 6 (2), 55-58.

Neely, L., Rispoli, M., Camargo, S., Davis, H., $\&$ Boles, M. (2013). The effect of instructional use of an $\mathrm{iPad}{ }^{\circledR}$ on challenging behavior and academic engagement for two students with autism. Research in Autism Spectrum Disorders, 7 (4), 509-516.

Nieves, L., Hamburger, Y., Vargas, Y., \& Escobar, A. (2019). Material Didáctico Multimedia para el reconocimiento de emociones básicas en niños con Trastorno del Espectro Autista. Revista de Ciencias de la Educación, Docencia, Investigación y Tecnologías de la Información CEDOTIC, 7494.

Ospina, M. B., Seida, J. K., Clark, B., Karkhaneh, M., Hartling, L., \& Tjosvold, L. (2008). Behavioural and developmental interventions for autism spectrum disorder: a clinical systematic review. PloS one, e3755 (11), 3. 
Parsons, D., Wilson, N., \& Vaz, S. (2019). Appropriateness of the TOBY Application, an iPad Intervention for Children with Autism Spectrum Disorder: A Thematic Approach. Journal of Autism and Developmental Disorders, 1-14.

Pennington, R. (18 de August de 2006). Computer-Assisted Instruction for Teaching Academic Skills to Students with Autism Spectrum. Focus Autism Other Dev Disable.

Peters-Scheffer, N., Didden, R., Korzilius, H., \& Sturmey, P. (2011). A meta-analytic study on the effectiveness of comprehensive ABA-based early intervention programs for children with autism spectrum disorders. Research in Autism Spectrum Disorders, 5 (1), 60-69.

Pontes, E., Kleparde, A., Silva, T., Puggina, A., Apostolico, M., \& PinaOliveira, A. (2019). Tecnologias Digitais e Recursos Físicos $\mathrm{Na}$ Abordagem de Crianças Com Transtorno do Espectro Autista. Revista Saúde-UNG-Ser, 6874.

Rana, A., \& Mridu, M. (2012). Analytical Comparison of usability Measurement Methods. Int. J. Comput. Appl., 39, 11-18.

Riihiaho, S. (2000). Experiences with usability evaluation methods.

Ringdahl, J., Kopelman, T., \& Falcomata, T. S. (2009). Applied behavior analysis and its application to autism and autism related disorders. In Applied behavior analysis for children with autism spectrum disorders (pp. 1532). New York: Springer.

Roschelle, J., Pea, J., Hoadley, C., Gordin, D., \& Means, B. (2001). Changing How and What Children Learn in School with Computer-Based Technologies. Future Child, 10 (2), 76-101.

Rutter, M. (2007). Progress in Understanding Autism. 2009.

Schmidt, C., \& Heybyrne, B. (2004). Expanding behavioral strategies and promoting success. Autism in the School-Aged Child. Autism Family Press, 71-78.
Siegel, D. J. (2001). Toward an interpersonal neurobiology of the developing mind: Attachment relationships "mindsight," and neural integration. Infant mental health journal, 22 (1-2), 67-94.

Weiss, P. L., Gal, E., Cobb, S., Millen, L., Hawkins, T., Glover, T., et al. (2011). Usability of Technology Supported Social Competence Training for Children on the Autism Spectrum. International Conference on Virtual Rehabilitation (pp. 27-29). Rehab Week Zurich.

Weng, P., \& Bouck, E. (2019). Comparing the effectiveness of two app-based number lines to teach price comparison to students with autism spectrum disorders. Disability and Rehabilitation: Assistive Technology, 281-291.

Yang, J. C., \& Chen, S. Y. (2010). Effects of gender differences and spatial abilities within a digital pentominoes game. Computers \& Education, 55 (3), 1220-1233.

Yee, K. P. (2004). Alingning security and usability. IEEE Security Privacy Magazine, 2 (5), 48-55. 